\title{
Investigating Students' Attitude towards Learning Mathematics
}

\author{
Mzomwe Yahya Mazana ${ }^{1,2^{\star}}$, Calkin Suero Montero ${ }^{2}$, Respickius Olifage Casmir ${ }^{1}$ \\ ${ }^{1}$ College of Business Education, Dar es Salaam, TANZANIA \\ ${ }^{2}$ University of Eastern Finland, School of Computing, Joensuu, FINLAND \\ *CORRESPONDENCE: y.mzomwe@cbe.ac.tz
}

\begin{abstract}
Students' learning of and performance in mathematics is affected by a number of factors, including students' attitude towards the subject, teachers instructional practices, and school environment. This study was conducted to investigate students' attitudes towards learning mathematics in Tanzania. It also sought to ascertain reasons for the liking or disliking mathematics and the relationship between attitude and performance. We employed the ABC Model and the Walberg's Theory of Productivity to investigate students' attitudes towards mathematics and associated factors. The quantitative and qualitative data were collected from 419 primary school students, 318 secondary school students, and 132 College students from 17 schools and 6 colleges in mainland Tanzania using a survey. The collected data were analysed using percentages, means, standard deviations, ANOVA, correlation, regression and thematic analysis. The results show that initially students exhibit a positive attitude towards mathematics, but their attitude becomes less positive as the students move forward to higher levels of education. A significant positive weak correlation between students' attitude and performance was established. Mathematics' enjoyment and attitude significantly predicted students' performance in our data. The factors influencing the students' liking or disliking of mathematics constituted student's aptitude attribute, instructional and social psychological environmental factors. Furthermore, the results show that failure in examinations is attributed to teacher didactic strategies, institutional resources, poor learning and examination strategies, and failure to understand instructions. The results provide insights for future research and inciting changes in teaching- learning practices that would promote mathematics enjoyment and subsequent better performance in the subject.
\end{abstract}

Keywords: students' attitude, mathematics, students' performance, Tanzania

\section{INTRODUCTION}

Mathematical ability is crucial for the economic success of societies (Lipnevich, MacCann, Krumm, Burrus, \& Roberts, 2011). It is also important in the scientific and technological development of countries (Enu, Agyman, \& Nkum, 2015). This is because mathematics skills are essential in understanding other disciplines including engineering, sciences, social sciences and even the arts (Patena \& Dinglasan, 2013; Phonapichat, Wongwanich, \& Sujiva, 2014; Schofield, 1982). Abe and Gbenro (2014) point out that mathematics plays a multidimensional role in science and technology of which its application outspread to all areas of science, technology as well as business enterprises. Due to the importance that mathematics engulfs, the subject became key in school curriculum. According to Ngussa and Mbuti (2017), the mathematics curriculum is intended to provide students with knowledge and skills that are essential in the changing technological world.

In Tanzania, mathematics is one of the core mandatory subjects to all students in primary and ordinary level secondary schools (Lower secondary). For example, in ordinary level secondary school curricula, there

Article History: Received 12 October $2018 \bullet$ Revised 23 November $2018 \bullet$ Accepted 2 December 2018

(C) 2019 by the authors; licensee Modestum Ltd., UK. Open Access terms of the Creative Commons Attribution 4.0 International License (http://creativecommons.org/licenses/by/4.0/) apply. The license permits unrestricted use, distribution, and reproduction in any medium, on the condition that users give exact credit to the original author(s) and the source, provide a link to the Creative Commons license, and indicate if they made any changes. 
are seven core subjects, notably, Mathematics, Geography, Kiswahili, English, Civics, History, and Biology (Ministry of Education and Vocation Training, 2007). Yet, mathematics is seen as the most difficult subject in many parts of the world (Ignacio, Nieto \& Barona, 2006) and Tanzania is not exceptional. According to Mabula (2015), the overall performance of students in Certificate of Secondary Education Examination in Tanzania has been deteriorating in the last fifteen years. Ngussa and Mbuti (2017) point out that, high failure rates in mathematics are due to several reasons which eventually disorient students' learning. For example, the results issued by the National Examinations Council of Tanzania (NECTA) in 2004 indicate that $66.6 \%$ of standard 7 and $70.1 \%$ of ordinary level secondary school students failed their final year mathematics examination. In 2016, the failure rates still stood at $53.4 \%$ and $81.9 \%$ for primary and secondary schools respectively (NECTA, 2016). The continued trend of poor performance in mathematics raises concerns to the public on whether or not the education system can supply graduates who possess the essential skills to enable them to cope with the ever-evolving technological society (Hamilton, Mahera, Mateng'e \& Machumu, 2010). These results provide an avenue for further research that seeks to characterise and understand the various factors that may influence students' performance in mathematics. This will help to devise plausible strategies for future action so as to bring about an improvement in the pass rates in mathematics.

Factors that can influence mathematics performance are demonstrated by Kupari and Nissinen (2013); Yang (2013); Tshabalala and Ncube (2016), when they show that poor performance in mathematics is a function of cross-factors related to students, teachers and schools. Among the students' factors, attitude is regarded by many researchers as a key contributor to higher or lower performance in mathematics (Mohamed \& Waheed, 2011; Mata, Monteiro \& Peixoto, 2012; Ngussa \& Mbuti, 2017). Attitude refers to a learned tendency of a person to respond positively or negatively towards an object, situation, concept or another person (Sarmah \& Puri, 2014). Attitudes can change and develop with time (Syyeda, 2016), and once a positive attitude is formed, it can improve students' learning (Akinsola \& Olowojaiye, 2008; Mutai, 2011). On the other hand, a negative attitude hinders effective learning and consequently affects the learning outcome henceforth performance (Joseph, 2013). Therefore, attitude is a fundamental factor that cannot be ignored. The effect of attitude on students' performance in mathematics might be positive or negative depending on the individual student. In response to this problem, this study seeks to investigate students' attitudes towards learning mathematics in Tanzania.

In accordance with Syyeda (2016) attitude has three main components: affect, cognition and behaviour. The components are interrelated and involve several aspects contributing to the overall attitude towards learning mathematics. We draw from the ABC (Affective, Behavioural and Cognitive) model (Ajzen, 1993) to investigate the students' attitude towards mathematics and the Walberg's theory of productivity (Walberg, Fraser, \& Welch, 1986) to interpret results about the factors influencing a like or dislike of mathematics and those impacting students' performance. Walberg's theory postulates that individual students' psychological attributes and the psychological environments surrounding them influences cognitive, behavioural and attitudinal learning outcomes. This theory will be relevant for this study because it is a suitable lens through which we can explain the reasons for the attitudes that students form towards mathematics. In line with the ABC model, our study focuses on investigating attitude aspects, including: students' self-confidence in their mathematics ability, mathematics anxiety, mathematics enjoyment, perception about the usefulness of mathematics and intrinsic motivation. Questions that guided the study are as follows:

1. What are the students' attitudes towards learning mathematics?

2. Why students acquire a like or a dislike towards mathematics?

3. What is the relationship between each attitude aspects and students' performance (grades)?

4. What is the relationship between attitude and student grades?

This work is relevant since poor performance in Science Technology Engineering and Mathematics (STEM) particularly in mathematics is seen as a barrier towards achieving economic and social development, both at the individual and national level. In Tanzania, like any other country within Sub Saharan Africa (SSA), students consistently perform poorly in mathematics and science, which makes Tanzania lose economic advantages over other countries. Students' achievement in countries within SSA is ranked far below the average point in international assessments (Bethell, 2016; 38). Bethell further points out that the long-run development of countries in SSA requires significant improvements in STEM education if they are to benefit in a competitive global economy driven by new technologies. In this regard, it is important to find ways to improve students' performance in the subject. The study of students' attitudes towards mathematics with associated factors and their connection to academic performance is certainly worth examining. The results 
will provide teachers, students, parents, and other education stakeholders with information that will help to develop strategies to improve students' learning of mathematics.

\section{RELATED WORKS}

Students' attitude towards mathematics is given various definitions in the literature. For example, Kibrislioglu (2016) defines attitude towards mathematics as liking or disliking of the subject; a tendency to engage in or avoid mathematical activities; a belief that one is good or bad at mathematics; and a belief that mathematics is useful or useless. Tahar, Ismail, Zamani, and Adnan (2010) give a simpler definition. They define attitude as a positive or negative emotional disposition towards mathematics. From this, when defining attitudes towards mathematics, both aspects of beliefs and emotions should be considered. We adopt the definition by Tahar, et al. (2010) because it looks better at students in both the cognitive and social perspectives.

Several studies have demonstrated that attitudes towards mathematics are directly and significantly associated with students' performance. For instance, Mensah and Kurancie (2013) conducted a study in Ghana and found a significant positive correlation between students' attitude and performance. Similarly, Nicolaidou and Philippou (2003) found that attitude and achievement in mathematics are significantly related. The Trends in International Mathematics and Science Survey (TIMSS) results of 2007 reported in Gonzales, et al. (2008) also indicate that 4th grade and 8th grade students with a more positive attitude had higher average achievement in mathematics as compared to those with less positive attitudes. In another earlier study conducted by Schofield (1982), a significant relationship between attitude and achievement was also established depicting stronger relationships in boys than in girls. In a more recent study, Ngussa and Mbuti (2017) conducted a study in Arusha, Tanzania, involving secondary school students. They established a moderate relationship between student's attitude and performance when teachers use humour as a teaching strategy. They concluded that the enhancement of students' positive attitude can boost students' performance in mathematics. However, Joseph (2013) in his study of community secondary school students in Kagera, Tanzania found that the majority of students (55\%) had a general negative attitude towards mathematics, with a positive and significant correlation between attitude and performance $(r=0.33)$.

Although these studies were carried out in Tanzanian contexts, however, they fall short in scope, reflecting only the situation in specific schools or segment of society. Our study differs in the size of the scope of our work in which we surveyed the situation of the country as a whole and at all levels of education. Our study also differs in approach and the depth of analysis. Previous studies used only quantitative approach and explored either instructional or school-related factors. Our study differs in approach in which we have used mixed methods, and went further to explore aptitude, instructional as well as social environmental factors influencing students learning cognitive and attitudinal outcomes to gain a deeper understanding of the problem.

The literature shows that students' attitude is affected by numerous factors. They include such factors as the school, peer students, home environment and society (Yang, 2013). Researchers, Yllmaz, Altun, and Olkun (2010) identify factors that include connecting mathematics with real life, using instructional materials, teachers' personality, teachers' content area knowledge, bad instructional practices, lack of commitment by students' and teachers' classroom management. Other factors include teachers' emotional support (Blazar \& Kraft, 2017), teachers' affective support (Sakiz, Pape, \& Hoy, 2012), class activities, subject content and amount of work, scarcity of teachers and inadequate resources (Joseph, 2013; Enu et al., 2015), peer and parental influence (He, 2007). Furthermore, in line with Simmers (2011) the factors also include, creating insecurities in students' mathematics ability and teacher failure to provide explanations for the mathematical concepts being taught.

According to Yilmaz et al. (2010), factors responsible for students liking of mathematics are good teaching and course enjoyment. While factors such as boring teachers, students' failure to solve mathematics problems, failure to understand the topic well, friends talking during lectures, receiving a bad grade for an examination are related to the students' disliking of mathematics.

The reviewed studies show a number of factors influencing students' liking or disliking of mathematics. These factors are related to students as learners, peers, instructional practices and classroom or school environment, the present study use these theoretical foundations to build an understanding of the various factors influencing students' attitude towards learning mathematics and those that hinder students learning 
of mathematics from the empirical study conducted in Tanzanian. It then expands our understanding regarding different factors influencing students' attitude towards mathematics learning.

\section{THEORETICAL FRAMEWORK}

\section{The ABC Model of Attitude}

The ABC Attitude Model is also called a Tripartite Model. It serves as a useful theoretical framework for developing mathematics attitude measures. The ABC Model of Attitude is based on a Hierarchical Model described in Ajzen (1993) who conceptualises an attitude as an amalgam of three separate measurable components: affect (A), behaviour (B) and cognition (C). Affect is the emotional component consisting of feelings and emotions that are associated with an attitude object (in our study mathematics). The behaviour is the action component consisting of predispositions to act in a particular way towards the attitude object. Cognition is a mental component that consists of belief and perceptions people hold about the attitude object. These three components must be present before we say that an attitude exists. A particular attitude may consist a positive emotion that is, feeling happy in a mathematics classroom (affect), intend to learn more mathematics (behaviour) and belief that mathematics is easy to learn (cognition). Students may form a favourable or an unfavourable attitude towards mathematics.

Students acquire attitudes over time through direct experience of learning mathematics or by receiving information about the mathematics subject. Students use the learned attitudes as a guide to their overt behaviour with respect to mathematics learning, resulting in consistently favourable or unfavourable patterns of reactions towards the subject. Attitudes are assumed to be precursors of mathematics learning behaviour. In predicting behaviour based on a particular attitude, Ajzen and Fishbein (1977) postulate that there should be a correspondence between measures of attitude and those of behaviour. Students' attitude to mathematics represents their evaluation of learning mathematics as a subject. Attitudes can be verbal or non-verbal actions (Ajzen, 1993). Several researchers have attempted to measure attitude using different instruments. Ajzen (ibid) proposes three measures of behaviour. They include observable actions performed by the subjects that are recorded by the investigator, individual commitment to perform the behaviours, and self-reported behaviour. However, the last two measures can only be considered if it becomes difficult to make direct observations of certain behaviours. High correspondence between attitude and behaviour measures can be achieved through standard scaling measures like Likert scale (Ajzen \& Fishbein, 1977) which we have adopted in this study.

\section{Attitude}

Attitude refers to a learned tendency of a person to respond positively or negatively towards an object, situation, a concept, or a person. It is also regarded as a belief held by individuals that reflects their opinions and feelings and can be sometimes manifested in behaviour (Joseph, 2013). Attitudes, behaviour, and feelings are interrelated in such a way that people's attitudes determine their behaviour towards objects, situations, and people. They also influence the relationships that exist among these variables with themselves (Joseph, 2013).

Attitude is a hypothetical construct that cannot be observed directly, but can be inferred from measurable reactions to the attitude object (Ajzen, 1993), as it is the case in our study, learning math. In accordance with Syyeda (2016), attitude is multidimensional. It takes into account three components: affect, cognition, and behaviour. Affect is composed of emotions, beliefs, and vision of the subject. Emotions are the feelings of enjoyment or pleasure in learning the subject or seeing it as boring, difficult, and dull. Beliefs are related to students' confidence in their abilities to learn the subject. Vision represents students' perception regarding mathematics. Cognition represents the students' perceived usefulness of the subject. Conversely, behaviour is connected to students' motivation to learn that is reflected with student's actions, commitment, and performance in class.

Using these components to understand the students' attitude towards mathematics, we measure the following aspects:

- Self-confidence, anxiety, enjoyment (affect)

- Intrinsic motivation (behaviour)

- Perceived usefulness (cognition) 


\section{Attitude Aspects}

\section{Affect}

Self-confidence. Self-confidence in mathematics refers to student perceptions of self as a mathematics learner that include beliefs about one's own ability to learn and perform well in mathematics (Adelson \& McCoach, 2011). The result of Hannula, Maijala, and Pehkonen (2004) shows that self-confidence is an important factor that influences students' learning which in turn affects their performance in mathematics. Van der Bergh (2013) argues that students with high self-confidence believe in their abilities that they can be successful in learning mathematics, thus overcoming the fear of failing. These students are ready to take mathematical challenges which in turn increase their academic achievement; otherwise, students with low self-confidence do not believe in themselves, thus tend to avoid taking mathematics challenges (Adelson \& McCoach, 2011). Therefore, this leads into minimising the chances of expanding their mathematical skills and success. Hence, it is desirable to study the students' attitude towards their own confidence and how it relates to performance.

Mathematics anxiety. Mathematics anxiety is defined as a condition of emotional response towards mathematics whereby students experience negative reactions to mathematical concepts and testing (Chaman $\&$ Callingham, 2013). Accordingly, mathematics anxiety is a feeling of tension, helplessness and distress that impede the ability to concentrate and consequently affects learning of mathematics (Zakaria \& Nordin, 2008). Mathematics anxiety is believed to have an impact on attitude and motivation to learn mathematics, consequently on students' achievement (Getahun, Adamu, Andargie, \& Mebrat, 2016). It was established in the study by Hoorfar and Taleb, (2015) that mathematics anxiety is negatively correlated with metacognitive knowledge which is the ability to reflect, understand, and control one's learning. This means that the more anxious the students are, the less metacognitive knowledge they possess that in the long run hampers their performance. A comparative study conducted in Malaysia and Tanzania by Mohamed and Tarmizi (2010) in higher education institutions reveals a negative correlation between mathematics anxiety and achievement, and that anxiety has a significant impact on achievement. Since anxiety is related to students' attitudes and achievement in mathematics, it is worth examining the level of anxiety of students at all levels of education.

Enjoyment of mathematics. Enjoyment of mathematics is the extent to which the students enjoy doing and learning mathematics (Kupari \& Nissinen, 2013). Students' enjoyment while learning can influence their behaviour or cognitive aspect of attitude (Syyeda, 2016). According to PISA 2012 results published by OECD (2013), students may learn mathematics because they find it enjoyable and interesting. They further posit that interest and enjoyment affect both the degree and continuity of engagement in learning and the depth of understanding. This means that the more students enjoy doing mathematics the more they are likely to engage in problem-solving thus enhancing their learning and performance. Since enjoyment, students' learning and performance are related, it is worth evaluating the students' status of mathematics enjoyment in order to keep track of students' learning and performance.

\section{Behaviour}

Intrinsic motivation. Intrinsic motivation in this study is related to both interest and the desire to learn mathematics (Guy, Cornick, \& Beckford, 2015). Students are intrinsically motivated to learn mathematics if they have the desire to do so after finding learning of mathematics interesting (OECD, 2013). It is believed that motivation is the driving force for learning (Yunus \& Ali, 2009). According to PISA results 2012 in OECD (2013), intrinsic motivation affects both the degree of student engagement, career choice, and performance. Therefore, studying motivational variables as related to attitude and achievement is crucial.

\section{Cognition}

Perceived usefulness. Perceived usefulness refers to students' perception about the importance of mathematics in the present everyday life and in the future (Adelson \& McCoach, 2011). Perceived usefulness of mathematics is believed to have an influence on students' attitude towards the subject. If students recognise the importance of mathematics in their lives, they will become motivated to study, practice, and learn the subject (Syyeda, 2016). This study also reveals that despite the fact that the majority of students had negative emotions towards mathematics they demonstrated positive cognition towards mathematics. This indicates students' recognition of the value of mathematics in their lives and future careers. The study by Guy, et al. (2015) found that mathematics usefulness is a positive predictor of success. Thus, it is worth studying the relationship between mathematics value, attitudes, and performance in Tanzanian context as well. 


\section{METHODOLOGY}

\section{Research Design}

In line with Hourigan, Leavy, and Carroll's (2016) view that there is no single instrument that can guarantee the complete truth, a parallel convergent mixed research approach was adopted in our research. We combined qualitative and quantitative methods to achieve a comprehensive view of the problem at hand. These methods complement each other's weaknesses and strengths (Denscombe, 2010, 150). Both quantitative and qualitative data were simultaneously collected, analysed separately for the purpose of establishing the facts. This is because the attitude is primarily measured by attitude scales that show whether the attitudes are positive or negative. Nevertheless, finding out the factors influencing attitude calls for qualitative methods (Yllmaz, et al., 2010).

\section{Participants}

The participants in this study constituted 869 students (409 males and 460 females) from public primary schools, secondary schools which include Ordinary level (Lower secondary) and Advanced level (Upper secondary), and colleges. The schools were selected from urban and semi-urban areas in five administrative regions, namely Dar es Salaam, Arusha, Mtwara, Dodoma, and Iringa in mainland Tanzania. Among the selected schools, sixteen were co-education and one was a single sex school but all schools had classes with mixed learning ability students. Students' social, economic and academic background in mathematics was taken into account.

As shown in Table 1, the majority of respondents were primary school students (48.2\%) followed by secondary school students (38\%). College students accounted for only $15.2 \%$ since this group did not return the questionnaires despite several follow-up attempts. Out of 250 questionnaires distributed to colleges only 132 (50.4\%) were returned duly filled-in.

Table 1. Summary of respondent's demography

\begin{tabular}{llcc}
\hline & Variable category & $\mathbf{N}$ & Percentage \\
\hline \multirow{2}{*}{ Gender } & Male & 409 & 47.1 \\
\cline { 2 - 4 } & Female & 460 & 52.9 \\
\hline \multirow{3}{*}{ Age } & Under 14 & 419 & 48.2 \\
\cline { 2 - 4 } & $14-20$ & 330 & 38.0 \\
\hline \multirow{2}{*}{ Study Level } & $21-27$ & 113 & 13.0 \\
\cline { 2 - 4 } & Above 34 & 6 & 0.7 \\
\hline & Primary & 419 & 48.2 \\
\hline & Secondary & 318 & 36.6 \\
\hline
\end{tabular}

\section{Sampling}

The regions were sampled based on multistage sampling technique. In this case, regions were grouped according to five zones, then from each zone one region was selected, one district was randomly selected from each region and from which schools and colleges were selected. According to Kothari $(2004,66)$, a multistage sampling technique is appropriate when the study involves a large area. Since the population was geographically scattered, the selection of students followed the inclusion and exclusion criteria known as a three stage stratified cluster sampling technique (Mabula, 2015). In accordance with this procedure, the population of the selected schools excludes all other schools and the population of the selected classes excluded all other classes. With this rule in mind, we were able to select one class at each grade level in each of the selected schools and finally students randomly sampled in the selected classes filled in the questionnaires.

\section{Instruments}

The primary instrument for collecting data in this study was the Mathematics Attitude Questionnaire (MAQ). The MAQ is composed of open-ended questions and a 5-point Lickert scale survey with 58 statements. The Likert scale survey was adapted from Fennema and Sherman (1976), Tahar et al., (2010), Sundre, Barry, Gynnild, \& Ostagard (2012) in order to ensure content validity. Five attitude aspects were considered: self- 
confidence in mathematics, perceived usefulness, and enjoyment of mathematics, mathematics anxiety, and intrinsic motivation. A description of each aspect, a corresponding sample statement and the Cronbach's Alpha is displayed in Table 2. All statements composing attitude aspects were scored on a 5-point scale ranging from $5=$ strongly agree to 1 = strongly disagree. The Cronbach's Alpha reliability scores for the sample in five attitude aspects was adequate as Cronbach's Alpha values range between 0.6 and 0.83 . This is in accordance with Abe and Gbenro (2014) that the reliability coefficient of instruments should lie between 0.5 and 0.85 or above.

Table 2. Description of the scale items and sample items

\begin{tabular}{|c|c|c|c|}
\hline & $\begin{array}{l}\text { Attitude } \\
\text { aspect }\end{array}$ & Description & $\begin{array}{c}\text { Cronbach's } \\
\text { Alpha }\end{array}$ \\
\hline \multirow[t]{3}{*}{ Affect } & $\begin{array}{l}\text { Self- } \\
\text { confidence }\end{array}$ & $\begin{array}{l}\text { A Likert scale with nine statements was adapted from Fennema } \\
\text { and Sherman (1976). It was meant to measure the students' } \\
\text { confidence in learning mathematics. Sample statement: "I am } \\
\text { sure that I can learn and understand mathematics" }\end{array}$ & 0.81 \\
\hline & $\begin{array}{l}\text { Mathematics } \\
\text { anxiety }\end{array}$ & $\begin{array}{l}\text { A Likert scale with six statements was adapted from Tahar et } \\
\text { al., (2010) and Sundre et al. (2012). It was meant to measure } \\
\text { students' anxiety when it comes to mathematics learning. } \\
\text { Sample statement: "Studying mathematics makes me feel } \\
\text { nervous". }\end{array}$ & 0.83 \\
\hline & $\begin{array}{l}\text { Enjoyment } \\
\text { of } \\
\text { mathematics }\end{array}$ & $\begin{array}{l}\text { A Likert scale with seven statements was adapted from Sundre } \\
\text { et. al. (2012). It was designed to measure students' enjoyment of } \\
\text { mathematics. Sample statement: "I get a great deal of } \\
\text { satisfaction out of solving a mathematical problem". }\end{array}$ & 0.69 \\
\hline Behaviour & $\begin{array}{l}\text { Intrinsic } \\
\text { Motivation }\end{array}$ & $\begin{array}{l}\text { A six statement Likert scale was adapted from Sundre et al., } \\
\text { (2012). It was meant for measuring students' intrinsic } \\
\text { motivation. This was after dropping two items to increase alpha. } \\
\text { Sample statement: "I plan to take as much mathematics as I can } \\
\text { during my education" }\end{array}$ & 0.60 \\
\hline Cognition & $\begin{array}{l}\text { Perceived } \\
\text { Usefulness }\end{array}$ & $\begin{array}{l}\text { A Likert scale with twelve statements adapted from Fennema } \\
\text { and Sherman (1976) measured perceptions of students on the } \\
\text { value of mathematics in their life and careers. Sample statement: } \\
\text { "Knowing mathematics will help me earn a living" }\end{array}$ & 0.82 \\
\hline
\end{tabular}

Mathematics performance was measured by self-reported grade based on the previous year/semester examination results. The grades were converted into 7 point scale ranges from 0 (F), 1 (E) to 7 (A). Given the inability of Likert scale items to explain reasons for the formation of and changes in attitudes (Hourigan et al., 2016), open-ended questions were considered. These questions gathered qualitative data regarding emotions, liking, disliking, and the reasons behind the liking or disliking of mathematics as well as identifying factors that affected students' learning of mathematics. There were five open-ended questions that are; Do you like mathematics? If yes, why do you like mathematics? If no, why you do not like mathematics? I like mathematics, but..., and when I study mathematics I feel...; these questions were developed to provide students a place to express their feelings and opinions without restrictions. They were designed to elicit strong reactions, thoughtful answers, and opinionated responses.

\section{Procedures and Ethics}

The research clearance was sought from the relevant authorities, including the Ministry of Education, Science and Technology, regional and district levels to conduct research in schools in Tanzania. Consent from parents was sought for their children's involvement in the study. Participants were informed about the purpose and nature of the research, both verbally and in writing. Voluntary participation and complete anonymity were guaranteed to all participants. Prior to commencing data collection, participants were requested to sign a consent form.

After obtaining the permission from a district education officer, the researchers met with the respective heads of the schools who facilitated meetings with the appropriate research participants. All students gave their consent through signing the consent form. In primary and secondary schools, MAQ was administered in the classrooms with the assistance of the class teacher during break time that took 30-40 minutes. Primary 
school pupils completed the MAQ in Kiswahili language as their medium of instruction. In colleges, questionnaires were delivered to the college authorities who distributed them to students.

The aim was to capture the views of individual students from all grade levels to college because issues concerning mathematics learning for primary students have been rarely addressed in Tanzania. Most studies have focused on secondary schools (Joseph, 2013; Ngussa \& Mbuti, 2017) so it was necessary to get the perspectives of mathematics from other groups of students. However, it was difficult to involve grade one to three students (aged 5-9 years) in filling out the MAQ as it was very long (58 statements) and the time to fill out the questionnaires was limited. Group interviews were conducted as recommended by Einarsdóttir (2007) taking into consideration that young children identify themselves easily in the presence of a friend. In this kind of environment, children are likely to be open and truthful in responding to questions (Shaw, Brady \& Davey, 2011). The open-ended questions in the MAQ were used as an interview guide to ensure consistency. The interview method offers the possibility for clarifications and helps in getting hold of information that would have been difficult to obtain. However, interviews are time consuming and there may be chances to lead the respondent (Randolph, 2008; 78-80).

Class teachers facilitated the delivery of consent forms to the parents, of which only children whose parents gave their consent were interviewed. Seven group interviews, each group formed by three participants, were conducted within the school premises and took about 15-25 minutes. The group interviews were done in four primary schools, one school in each of four selected regions. Data from group interviews were audio-recorded and field notes were written and finally were combined with open-ended question data collected from other students.

\section{Data Analysis}

\section{Quantitative data analysis}

A quantitative method was used to analyse quantifiable portion of the survey. Using SPSS 23.0 descriptive analysis, correlation analysis and binary logistic regression were performed. Data obtained from closed-ended items were coded and entered in the SPSS computer programme. At this point, negative items were scored in the reverse order. Mean scores were calculated for each statement of attitude aspect to get variables which were used in subsequent analysis. The first research question of the study required to establish the students' attitude towards mathematics. Towards this end, descriptive statistics such as mean and standard deviation were used where mean values of all attitude aspects were averaged to get the overall attitude. One way ANOVA with study level as an independent variable was used to account for the observed mean differences in the overall attitude and attitude aspects.

Correlation analysis was used to establish the relationship existing between variables. Binary logistic regression analyses were employed by taking attitude aspects and attitude as predictors of performance. The performance data were coded as F (0) = Fail and A, B, C, D, E (1) = Pass. The Model Fit was inspected using Hosmer and Lemeshow goodness of fit test statistics ( $p>0.05$ indicating good fit) and by considering the explained variance through the Negelkerke R-Square.

\section{Qualitative data analysis}

A descriptive method was used to analyse the responses to the open-ended but quantifiable items. Students' responses to questions: Do you like mathematics? When I study mathematics I feel..., were coded and arranged based on the emerged themes. Consequently, these qualitative data were transformed into descriptive frequencies (i.e. percentages) which were presented using bar charts.

Thematic analysis was used to analyse non-quantifiable data from the open-ended items (textual) and interviews (aural). The analysis was done manually and followed a number of stages. The first stage involved familiarisation with the data whereby the data were transcribed in such a way that textual data were recorded as close to verbatim as possible from the students' hand written responses. Then the transcriptions were read in a repeated manner while writing notes of the initial issues. In the second stage, the data were coded and verbal expressions relevant to each code were identified. The third stage involved sorting of different codes into the emerging themes and pulling together all relevant data extracts within the identified themes which were organised by using a table. In the next stage, the themes were reviewed to ascertain the relationships with the data set. The themes were then grouped into different subjects based on the research questions. Finally, verbal extracts were used to support the identified factors pertaining to students liking, disliking, and those that affected students' learning of mathematics. In the discussion section, the findings were mapped 
into the Walberg's theory of productivity. Details on the emerged themes and their classifications are given in the results section in relation to the research questions.

\section{RESULTS}

\section{Students Attitude towards Mathematics \\ Like or dislike of mathematics}

The respondents were asked about whether they liked or disliked mathematics. The responses were categorised into two themes, notably yes and no. Response frequencies were generated with the aid of Microsoft Excel, then presented by using a bar chart. There were 869 respondents in the full sample of which 860 answered the question while 9 did not answer the question. Of those who answered the question, 813 (94.5\%) said Yes, and 47 (5.5\%) said No. The responses of the full sample and by study levels are depicted in Figure 1.

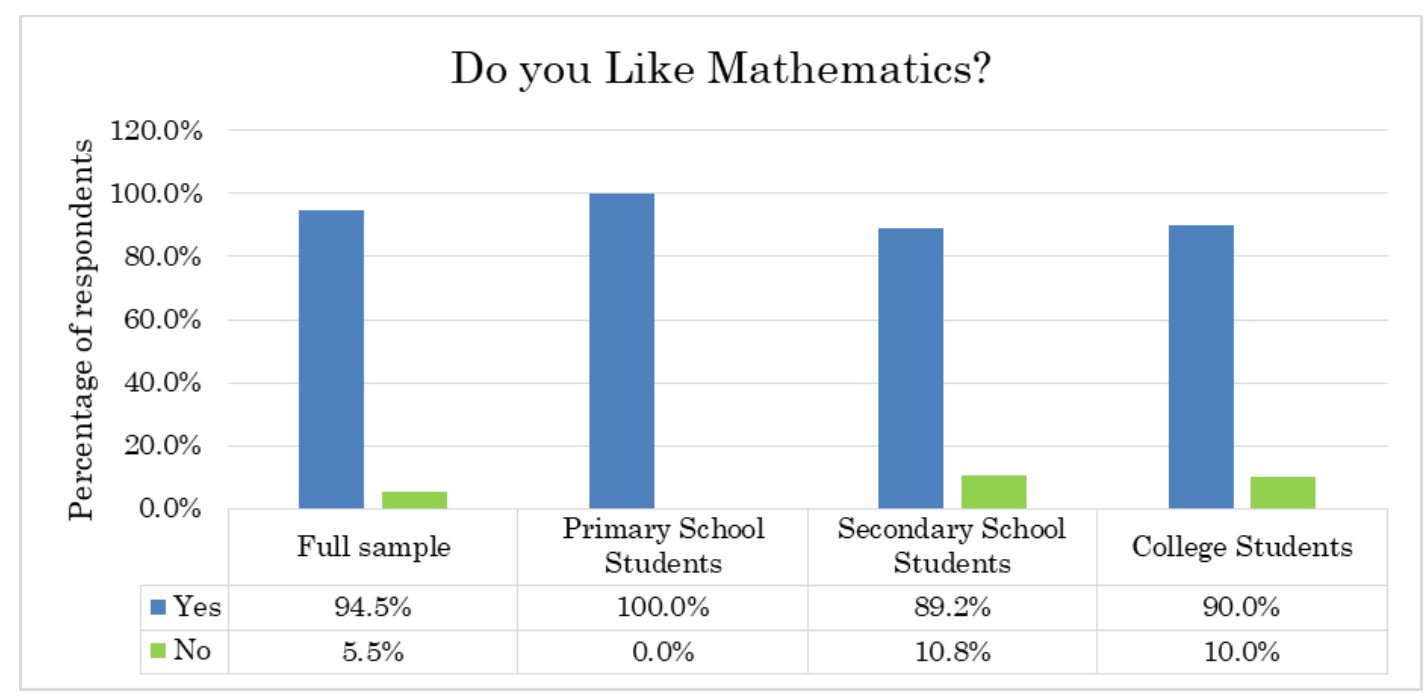

Figure 1. Response distribution by study level

Figure 1 shows that primary school students were more positive about mathematics since $100 \%$ of primary school respondents said yes. The participants of the remaining two groups showed similar feelings with the majority having positive opinions about mathematics $(89.2 \%)$ of secondary school and (90\%) of college respondents. In general, the results show that the majority $(94.5 \%)$ of students liked mathematics. This indicates that overall students exhibited positive attitudes towards mathematics, but their attitudes were higher at primary school, which dropped at secondary level and maintained a similar trend in higher education with a slight increase $(0.8 \%)$ in higher education.

\section{Emotions towards learning mathematics}

The respondents were asked about their feelings when studying mathematics. A total of 642 students answered this question of which 319 were primary students, 314 secondary students and 96 college students. There were 46 codes including positive and negative ones. The codes were grouped into two major themes, notably positive emotions such as "Good, awesome, secure..." and negative emotions such as "bad, insecure, hatred..." Out of these, frequencies were generated and presented in a bar chart. Figure 2 shows students' responses regarding emotions distributed by the level of study. No respondents gave a response that was considered to reflect both positive and negative emotions. 


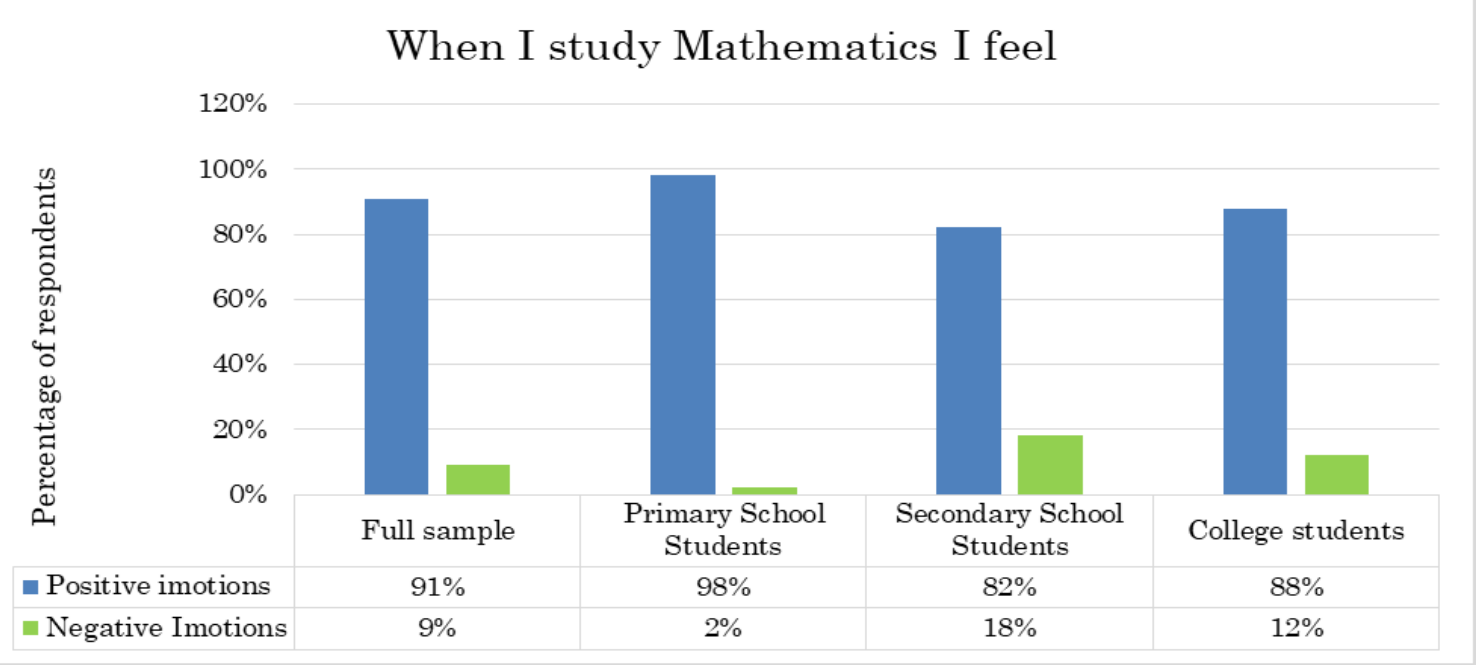

Figure 2. Students' emotions regarding mathematics

Broadly speaking, respondents in the sample indicated positive emotions (91\%) of all respondents. The majority of primary school participants (98\%) showed more positive emotions. The results indicate that negative emotions begin to develop early in primary schools (2\%) but they become noticeable in secondary schools where $18 \%$ of the respondents showed negative emotions. Generally, students had a positive attitude towards mathematics. However, there was a small proportion of students who exhibited negative attitude. Thus, they should not be ignored as positive attitudes are desirable for effective learning of mathematics.

Furthermore, the mean score and standard deviation for the Likert scale data for all attitude aspects were calculated. Descriptive and inferential statistics for attitude and attitude aspects are depicted below. Out of the 869 administered questionnaires, 50 were excluded from the analysis because they were not duly filled-in. Therefore, the remaining 819 questionnaires were subjected to analysis.

\section{Overall attitude towards mathematics}

In order to say that a student has a positive attitude towards mathematics, he or she has to at least score a mean value above 3.0, the midpoint of the scale. As presented in Table 3, the attitude scores vary between 3.74 and 4.36 for groups organised by the study level. These values are above 3.0 indicating that the overall students possessed positive attitudes towards mathematics and that primary students presented more positive attitude $($ mean $=4.36)$.

$\underline{\text { Table 3. Descriptive statistics for the overall students' attitude towards mathematics }}$

\begin{tabular}{lcccccc}
\hline & \multicolumn{2}{c}{ Primary } & \multicolumn{2}{c}{ Secondary } & \multicolumn{2}{c}{ College } \\
\hline $\mathbf{N = 8 1 9}$ & $\mathrm{M}$ & S.D & $\mathrm{M}$ & S.D & $\mathrm{M}$ & S.D \\
\hline Attitude & 4.36 & 0.49 & 3.74 & 0.63 & 3.89 & 0.66 \\
\hline
\end{tabular}

To clarify the mean differences in the overall attitude (Table 3) one way ANOVA with study level as an independent variable was performed. The results show a significant effect on attitude towards mathematics, $\mathrm{F}(2,803)=103.233, \mathrm{p}<0.001, \mathrm{n}^{2} \mathrm{p}=0.2$, a Tukey post hoc test shows that attitudes' became less positive as students advanced from primary (mean $=4.36)$ to secondary (mean $=3.74)$, but there was a slight increase in colleges $($ mean $=3.89) ;(p<0.05$, from primary to secondary; $p=0.03$ secondary to college $)$ but the effect size is small.

\section{Affect}

Self-confidence. Scores above 3.0 on this aspect represent high self-confidence whereas scores below 3.0 indicate low confidence. The results presented in Table 4 show that primary students had more confidence in mathematics, mean $=4.13$ when compared to secondary students mean $=3.69$ and college students mean $=$ 3.99 . 
Table 4. Descriptive statistics regarding self-confidence

\begin{tabular}{lcccccc}
\hline & \multicolumn{2}{c}{ Primary } & \multicolumn{2}{c}{ Secondary } & \multicolumn{2}{c}{ College } \\
\hline $\mathbf{N = 8 1 2}$ & $\mathrm{M}$ & $\mathrm{SD}$ & $\mathrm{M}$ & $\mathrm{SD}$ & $\mathrm{M}$ & SD \\
\hline Self confidence & 4.13 & 0.71 & 3.69 & 0.79 & 3.99 & 0.77 \\
\hline
\end{tabular}

${ }^{*} \mathrm{~F}(2,812)=29.45, \mathrm{p}<0.001, \mathrm{n}^{2} \mathrm{p}=0.073$, Primary - secondary $\mathrm{p}<0.001$, Secondary - College $\mathrm{p}=0.01$

The results show significant differences between primary, secondary and college students' self-confidence in mathematics, but the effect size was very small.

Mathematics Anxiety. High scores on this aspect represent low anxiety while a low score means high anxiety. By looking at Table 5, one can see that primary students possessed lower anxiety levels, mean $=4.8$, while secondary and college students showed a moderate anxiety, mean $=3.21$ for secondary and 3.39 for college students.

Table 5. Descriptive statistics for mathematics anxiety

\begin{tabular}{lcccccc}
\hline & \multicolumn{2}{c}{ Primary } & \multicolumn{2}{c}{ Secondary } & \multicolumn{2}{c}{ College } \\
\hline $\mathbf{N}=\mathbf{8 1 2}$ & $\mathrm{M}$ & $\mathrm{SD}$ & $\mathrm{M}$ & $\mathrm{SD}$ & $\mathrm{M}$ & $\mathrm{SD}$ \\
\hline $\begin{array}{l}\text { Mathematics } \\
\text { anxiety }\end{array}$ & 4.28 & 0.86 & 3.21 & 1.12 & 3.39 & 0.99 \\
\hline
\end{tabular}

${ }^{*} \mathrm{~F}(2,812)=109.063, \mathrm{p}<0.001, \mathrm{n}^{2} \mathrm{p}=0.21 ;$ primary and secondary $\mathrm{p}<0.001$, secondary and college, $\mathrm{p}=0.194$.

This indicates significant differences between primary and secondary students' anxiety $(p<0.001)$, but the difference between secondary and college students' anxiety was not significant $(p=0.194)$.

Enjoyment of mathematics. A student who scored above 3.0 really enjoyed mathematics and the one who scores below 3.0, had low enjoyment. As depicted in Table 6, the mean scores were above 3.0, indicating that students really enjoyed mathematics, but primary students highly enjoyed the subject, mean $=4.29$ when compared to older colleagues.

Table 6. Descriptive statistics for mathematics enjoyment

\begin{tabular}{lcccccc}
\hline & \multicolumn{2}{c}{ Primary } & \multicolumn{2}{c}{ Secondary } & \multicolumn{2}{c}{ College } \\
\hline $\mathbf{N}=\mathbf{8 1 2}$ & $\mathrm{M}$ & $\mathrm{SD}$ & $\mathrm{M}$ & $\mathrm{SD}$ & $\mathrm{M}$ & SD \\
\hline Enjoyment & 4.29 & 0.63 & 3.69 & 0.75 & 3.84 & 0.76 \\
\hline
\end{tabular}

${ }^{*} \mathrm{~F}(2,812)=73.35, \mathrm{p}<0.001, \mathrm{n}^{2} \mathrm{p}=0.15$ primary- secondary $\mathrm{p}<0.05$; secondary to college $\mathrm{p}=0.041$

The results show significant differences between primary, secondary and college students in terms of enjoyment of mathematics, although the effect size is very small.

\section{Behaviour}

Intrinsic motivation. Similarly, the scores above 3.0 represent high motivation, below 3.0, low motivation. Table 7 shows that the mean values were above 4.0, indicating that students in the sample were highly motivated to learn mathematics.

Table 7. Descriptive statistics for intrinsic motivation

\begin{tabular}{lcccccc}
\hline & \multicolumn{2}{c}{ Primary } & \multicolumn{2}{c}{ Secondary } & \multicolumn{2}{c}{ College } \\
\hline $\mathbf{N}=\mathbf{8 1 2}$ & $\mathrm{M}$ & $\mathrm{SD}$ & $\mathrm{M}$ & $\mathrm{SD}$ & $\mathrm{M}$ & $\mathrm{SD}$ \\
\hline $\begin{array}{l}\text { Mathematics } \\
\text { anxiety }\end{array}$ & 4.59 & 0.57 & 4.10 & 0.96 & 4.25 & 0.92 \\
\hline
\end{tabular}

${ }^{*} \mathrm{~F}(2,812)=33.464, \mathrm{p}<0.001, \mathrm{n}^{2} \mathrm{p}=0.077 ;$ primary-secondary, $\mathrm{p}<0.001$, secondary- college, $\mathrm{p}=0.21$

The results show that no significant differences were found between secondary and college students' in terms of motivation $(p=0.21)$ but the difference between primary and secondary students is statistically significant. 


\section{Cognition}

Usefulness of mathematics. Results show that respondents in the three groups highly valued mathematics. As shown in Table 8, the mean scores ranged between 3.97 and 4.44 and that they are far above the midpoint of the scale (3.0).

Table 8. Descriptive statistics for mathematics usefulness

\begin{tabular}{lcccccc}
\hline & \multicolumn{2}{c}{ Primary } & \multicolumn{2}{c}{ Secondary } & \multicolumn{2}{c}{ College } \\
\hline $\mathbf{N}=\mathbf{8 1 5}$ & $\mathrm{M}$ & $\mathrm{SD}$ & $\mathrm{M}$ & $\mathrm{SD}$ & $\mathrm{M}$ & SD \\
\hline Usefulness & 4.44 & 0.54 & 3.69 & 0.71 & 3.97 & 0.74 \\
\hline
\end{tabular}

${ }^{*} \mathrm{~F}(2,812)=50.74, \mathrm{p}<0.001, \mathrm{n}^{2} \mathrm{p}=0.11$. Primary- secondary, $\mathrm{p}<0.001$, secondary- college, $\mathrm{p}=0.907$.

The results indicate no significant differences between secondary and college students in terms of the perceived usefulness of mathematics $(p=0.907)$. The differences between primary and secondary school students are statistically significant $(p<0.001)$. However, the effect size was very small.

Generally, the results indicate that students had confidence, did enjoy mathematics classes, they were motivated and found it useful. Significant differences were found between primary and secondary students in terms of self-confidence, usefulness, enjoyment, motivation, and anxiety albeit the small effect size. However, insignificant differences were established between secondary and college students in terms of usefulness, anxiety, and motivation.

\section{Reasons for a Like or Dislike of Mathematics}

The respondents were asked to give reasons for liking or disliking of mathematics. Their responses resulted in several themes that are discussed below.

\section{Why do you like mathematics?}

Initial coding of this question resulted in ten categories. In the next round, some categories were combined which resulted into six interpretable themes. They included, usefulness of mathematics, career prospects, having a good teacher, good results, and the encouragement, support received from others, and mathematics being a compulsory subject. Others were, enjoyment, the subject is interesting, confidence and ease.

Usefulness of mathematics: Some respondents said they liked mathematics because mathematics was useful in their lives as it could be applied in real-life situations. They said that most of the things they did in everyday life were about mathematics. When people go to church, home, school, shopping, and even when they travel, they apply mathematics. The quote from one respondent illustrates the finding "... mathematics is applied in our daily lives... when we are in the shop and in different aspects of business issues mathematics is applied..." (Lower secondary). The issue of mathematics being an aid in solving mathematics-related problems encountered in other subjects also arose; some respondents said that mathematical problems found in other subjects could be done when a person had mathematical knowledge. This is illustrated by one respondent's narration, "I like mathematics because I can apply this knowledge in different subjects like statistics..." (Upper secondary).

The issue of mathematics being an aid in critical thinking and decision making also emerged. Respondents opined that mathematics helped with critical thinking as one respondent narrated "... mathematics contains numbers and letters that help a student to have high thinking capacity and make a quick observation which makes them active in other subjects..." (Lower secondary), and that mathematics is an aid in decision making"... when you are making any plan of business you must apply mathematics in order to know whether the business is profitable or not..." (College). Students' opinions come from real-life experiences supporting the proximity of learning. Thus, teachers should capitalise in these principles while teaching.

Career prospects: With regards to career development, some respondents said that they expected to study mathematics in advanced levels. They perceived mathematical skills as essential when it is linked with their career aspirations like science, engineering, business, and the like. The following quote illustrates the finding “... I like to be a pilot or an engineer, so I will have to study mathematics because all combinations which I want to study consist of mathematics e.g. PCM, PGM” (Lower secondary). 
These findings suggest that students at different levels of education understood the value of mathematics in their present lives and future. Thus, mathematics teachers are advised to consider these aspects in their teaching practices.

Having a good teacher: Having a teacher who teaches for understanding, makes lessons enjoyable, a kind person and tolerant, is of crucial importance for students' engagement in mathematics. This is evidenced by quotes from two respondents “... Our teacher teaches well... when I study mathematics, I enjoy because we have a good teacher" (Lower secondary), another respondent narrated "... I like mathematics because our teacher is tolerant and kind..." (Primary). This result illustrates the importance of the teachers' personal and professional characteristics in students' liking of mathematics. Thus, teachers should open up for some characteristics that will help students develop a positive attitude towards the subject.

Good results: Having good results also surfaced as a reason for liking mathematics. Some respondents indicated that when a person receives a good grade in examinations, he or she is likely to engage in mathematics at higher levels. This is as one respondent narrated "I like mathematics because once I was at primary school, I used to perform well... in my last examination (NECTA) I got an A grade” (Junior Secondary).

Mathematics is a compulsory subject: Other respondents indicated that students liked mathematics because the subject was compulsory. A quote from one respondent support the finding “... because mathematics is among the mother subjects that are recommended by the Ministry of Education, Science and Vocational Training..." (Lower secondary). Mathematics is a compulsory subject in school education and in some college courses like engineering, science, and even business studies. Students are mandated to pass mathematics. This suggests that students liked mathematics because they felt obliged to do so that is why they are struggling with the subject hence poor performance.

The encouragement and support received from others: The respondents said that they liked mathematics due to the encouragement and support they received from parents, teachers, and fellow students. When students faced some difficulties in solving a mathematical problem, they needed someone to help. This is supported by the following quote "... my teachers and parents encourage me to practice myself. They correct me when I miss it" (Primary), “... When I face some difficulties in mathematics... I ask my teachers and fellow students, they explain well." (Primary). This implies that teachers, parents, and peers are crucial in building student's positive attitude towards mathematics.

Other respondents said they liked mathematics because they found mathematics ease to learn, interesting, and enjoyable. They also had confidence in themselves and were motivated to do so. The following quotes support the findings: "I enjoy when studying mathematics...”(Upper secondary), “... I like mathematics because I am very confident..." (Primary). This suggests that teachers should try to make lessons interesting and enjoyable for students' positive attitude and better performance.

\section{Why you do not like mathematics?}

The coding of this question resulted into six major themes, notably difficult, self-confidence, career prospect, the relevance of the subject matter, poor background, and receiving a bad grade.

Difficult: The respondents opined that they found mathematics difficult, believing that they were not good at mathematics and not being able to pass no matter how hard they tried. "... Mathematics is difficult"... much of my efforts I did I couldn't pass ..."(Lower secondary). For other Students' mathematics is difficult because of failure to attempt some questions due to the lack of understanding of some topics as a result, they receive poor grades, hence disliking mathematics "Sometimes I feel mathematics is difficult because I might be provided with math problems... while I have not understood... I end up receiving marks contrary to my expectations" (Primary). Others felt that mathematics was difficult due to less exercise and practice given "... Sometimes it is so difficult due to low practices and less exercise our teachers provide us" (Lower secondary).

Self-confidence: The respondents were of the view that they lacked confidence in themselves as mathematics learners. They believed that they were not good at mathematics. “... Because I am not good at mathematics..." (Lower Secondary). This illustrates the importance of self-confidence and that lack of confidence had a negative influence on the student's attitude towards mathematics. Thus, teachers should use strategies that will boost up students' confidence in mathematics.

Career prospects: The responses show that some students learned mathematics because it was relevant to what they aspired to be. If this link is not evident, they developed a dislike for the subject. Some respondents opined that, mathematics was not important for their careers. This is evident in the following quote: “... 
mathematics is not in my career... for me is not the thing that I like..." (College). This indicates that teachers should try to teach mathematics highlighting its applicability in different careers.

Receiving a bad grade: The responses indicate that some students did not like mathematics because of having bad examination results as compared to other subjects. One respondent's quote illustrates the finding “... mathematics causes someone to lose hope when he/she has failed while they have passed in other subjects..." (Lower Secondary). This highlights the importance of positive results in one's life, implying that negative results discourages students regarding mathematics hence disliking the subject.

The relevance of the subject matter: The respondents pointed out the fact that they disliked mathematics because of the feeling that other topics were not relevant to the daily life application, wondering about where one will use this. One respondent's answer supports the finding "Other topics do not relate to actual societal needs, like those of Algebra equation..." (Lower secondary). This illustrates the importance of emphasising on the application of mathematics in real- life experiences. Thus, teachers should give examples highlighting real-life applications of different mathematical concepts.

Poor background: The respondents mentioned a poor foundation as a factor contributing to difficulties in mathematics "... mathematics is the foundation of that career, but they have poor foundation..." (College). This implies that poor background is a hindrance to students' career choices.

\section{I like mathematics, but...}

This question aimed at identifying factors affecting students' learning of mathematics. The coding of this question initially broke down the responses into three themes labelled: student characteristics (10 codes), instructional/teacher characteristics ( 8 codes) and school/classroom administration (2 codes). Within these three themes 14 subthemes were identified which were shuffled and combined based on the three main themes.

\section{Student characteristics}

Within this category, subthemes, notably lack of seriousness, fear, discouragement from colleagues, English language problems, poor learning, and examination strategies, and failure to complete exams prevailed.

Lack of seriousness: The respondents mentioned the lack of seriousness as a hindrance to their own learning. This point is connected with issues of the lack of enough exercises, time to practice and efforts. Some respondents mentioned that they could not find time to take enough exercises to work out some mathematics problems "It needs a lot of time to practice in order to keep the contents and formulas in the head, which is very hard for me to do due to the lack of time" (College). This affected them as mathematics requires more exercises for clear understanding of the concepts.

Fear: The responses show that students developed fear in both mathematics as a subject and the teacher due to various reasons. With regard to the subject some students viewed mathematics as a difficult subject due to the lack of ability to comprehend mathematical concepts and tasks. Others feared to fail the examinations. For example, one respondent had this to say: "I am afraid of failing in my examination" (College). When it comes to the teacher, respondents raised concerns about their teacher's behaviour of being angry and the use of punishment. They opined that mathematics teachers' were angry. For instance, one had this to say: "... In primary school the teacher was so angry to the extent that he/she led some students to stop from attending the class. This caused many pupils to dislike mathematics" (Lower secondary). The use of punishment when a student has failed in a test or an exam makes students lose interest in the subject. To clarify this one responded had this to say: “... The fear of the stick when a student has failed and the teacher gives him or her punishment; it can make him or her hate the subject...”(Lower secondary). Most of the answers pinpoint on teachers' behaviour as affecting students negatively towards mathematics learning. These practices discourage students as they instil fear and by so doing the mathematics instructions become less enjoyable. Hence, students develop a dislike towards the subject.

Discouragement from colleagues: The respondents voiced about peers acting as a hindrance to mathematics learning. Some respondents opined that their peers were a bad influence as they instilled fear in them discouraging these students to learn mathematics. This is evidenced by the following statements: “... Some people can tell you that mathematics is really tough. When you think about it, you may find that you are down because you believe in those people" (Lower secondary). This result points out the influence of peers in emotional and academic well-being of students. Peers can have both positive and negative influences regarding their colleagues' mathematics learning. 
English language problems: The responses show that a change of language, of instruction from Kiswahili in primary schools to English in secondary schools is a problem. These students did not have a background in this language that makes it difficult to understand instructions. This is evidenced by the quote "... how come someone who has a foundation of learning mathematics in Swahili and when he or she goes to secondary school, he or she starts using English. It is a problem.” (Lower secondary). This result shows that secondary school students are not conversant with English language. English is a language of instruction in public secondary schools. So efforts should be made to help students understand the language.

Poor learning and examination strategies: The responses indicate that students lack learning and examination strategies such as speed and accuracy. Some of them opined that even if they solved a question several times, they would not be able to get it right in the examination. This is evidenced by one respondent's quote "... I have always lacked three qualities ... which will make an examiner to be convinced with my answers that is accuracy, speed, and techniques" (College), "I use to cram formulas so as to pass exams..." (Upper secondary). This suggests that students adopted surface learning approaches and that they might fail due to a particular study habit. In this case, they should develop the best study techniques that will enhance their understanding.

Failure to complete examinations: The responses point out the issues of mismatch between time allocation, students' understanding of the subject matter, and depth of exam questions. This is supported by a quote from one respondent "Sometimes you are given time to do mathematics, sometimes the questions are difficult and have lengthy procedures... the time is not enough, where I could get $80 \%$ I end up with $70 \%$..."(Primary). This implies that time allocation should be proportional to the level of difficulty of the examination questions and the level being examined.

\section{Instructional/Teacher characteristics}

Five subthemes emerged; these are Syllabus coverage, linkage to real-life experiences, ineffectiveness, and perception about students' ability.

Syllabus coverage: Two issues arose; the syllabus is very long and high pace of instruction due to the same. The respondents raised issues related to teachers' failure to complete the syllabus because it was very long. As a result, teachers moved very fast. This made it hard for students to follow the instructions. For example, one of the respondents had this to say: “...Many students in Tanzania fail in mathematics exams because many teachers don't finish their syllabus at the respective time...” (Lower secondary). Uncompleted syllabus has a direct effect on students' performance because if it happens the uncovered content appears in the examination, the students will not be able to attempt, hence poor grades.

Linkage to real-life experiences: Another issue is related to teachers' failure to connect mathematics to real-life experiences. With regard to this, the respondent said that mathematics was taught as if it was an abstract subject. This made it difficult to make sense of what was being taught. "... Sometimes teachers fail to link mathematics to real-life experiences..." (College). This is linked to teachers' failure to provide examples relevant to everyday life applications. Thus, teachers should give examples or cases illustrating real-life application of mathematics to motivate students.

Ineffectiveness: The Respondents also voiced their concern regarding the instructional strategies and pace of instruction. Their answers revolved around teachers who could not be well understood and that the methods employed were not appropriate. Not only that, but the respondents also mentioned other hindrances which included lengthy syllabi, speed of teaching and boredom. The students connected this with receiving poor grades. The following quotes support the finding: "I fail to get good grades because the lecturers fail to use proper techniques for me and others to do well. The teachers who teach mathematics are very fast in teaching..." (College). "It has a long syllabus, so the teacher needs to go very fast to finish the syllabus...”(Upper secondary). Others opined that teaching approaches like group discussion may help "I need more assistance from a group discussion..." (College). It seems that teachers did not take into consideration different types of learners as slow learners need more time to learn new content. This implies that collaborative teaching strategies are of vital importance for students' enhanced learning.

Perception about students' ability: The responses revolved around factors related to teachers' perception regarding their students' ability to learn mathematics. The following quotes support the findings: “... Sometime the teacher who teaches mathematics gives up teaching student because they believe students whom they teach can fail..." This practice may discourage and drive away students especially the low ability ones who need some encouragement and support from teachers. This implies that low ability students really felt ignored and unsupported. This discouraged them from studying. 


\section{School/Classroom administration}

Three codes correspond to this category; teacher scarcity, and scarcity of learning materials and resources that were grouped into one subtheme named scarcity of teachers and learning materials. Another theme under this category is friends chatting during classes.

Scarcity of teachers and learning materials: The respondents raised their concerns regarding the scarcity of teachers, learning materials, and resources such as textbooks, equipment and the like. The students had the feeling that the unavailability of resources affected learning in a negative way. The quote from one respondent support the finding: "There is a shortage of mathematics teachers in our school. There is only one teacher... to pass examinations for me will be difficult. Our school also has a shortage of materials for learning mathematics like libraries, computers..." (Lower secondary).

The students also said that the few available teachers were unable to give the needed support to students. There were not enough teachers to assist me in studying mathematics. So, I find difficult to learn...” (Lower Secondary). This result implies that, the scarcity of teachers in schools greatly affected students' learning. The students might fail due to the lack of support as a result of the unavailability of teachers to provide them with support. This type of answers came mostly from secondary school students. This may explain the drop in attitude and performance at this level. The implication is that this problem really affected secondary school students in a negative way.

Friends chatting during classes: The analysis of responses indicates that some students failed to understand the subject matter when others were talking as classes were in progress. The noises hindered students' understanding of mathematics and consequently affected their performance. "I am not able to understand well because when I study mathematics, students make noises that is why I am not able to perform well in my exams" (Primary). This implies that the atmosphere in the classroom was not good, hence teacher's skills in classroom management should be enhanced.

\section{Relationship between Students’ Attitude, Attitude Aspects and Performance Correlation analysis}

Bivariate correlations were calculated to examine the relationship between attitudes, attitude aspect and students' grade are presented in Table $\mathbf{9}$.

Table 9. Correlations between variables

\begin{tabular}{|c|c|c|c|c|c|c|}
\hline & Grade & Confidence & Enjoyment & Usefulness & Motivation & Anxiety \\
\hline Grade & - & & & & & \\
\hline Confidence & $0.171^{* *}$ & -...-. & & & & \\
\hline Enjoyment & $0.184^{* *}$ & $0.604 * *$ & 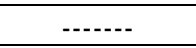 & & & \\
\hline Usefulness & $0.129^{* *}$ & $0.587 * *$ & $0.541^{* *}$ & - & & \\
\hline Motivation & $0.130^{* *}$ & $0.455^{* *}$ & $0.537^{* *}$ & $0.546^{* *}$ & -..-- & \\
\hline Anxiety & 0.059 & $0.522 * *$ & $0.461^{* *}$ & $0.566^{* *}$ & $0.278^{* *}$ & -..--.- \\
\hline Attitude & $0.170 * *$ & $0.784^{* *}$ & $0.773^{* * *}$ & $0.811^{* *}$ & $0.701^{* *}$ & $0.748^{* * *}$ \\
\hline
\end{tabular}

** Significant at 0.01 level

The correlation scores between students' mathematics grade and attitude aspects were generally positive, significant, but not strong. The most positive relationship highlights the association between attitude and most of the aspects. The correlation scores varied between 0.55 and 0.81 representing moderate to high positive correlations. However, the relationship between mathematics anxiety and mathematics grade was not significant.

\section{Regression analysis}

A logistic regression analysis was conducted to predict students' performance from confidence, enjoyment, usefulness, anxiety, motivation, and attitude. A test of the Full Model against Constant Only Model was statistically significant, indicating that the predictors reliably distinguished between the pass and failures $\left(x^{2}=63.416, p<0.001, \mathrm{df}=5\right)$. Negelkerke's $\mathrm{R}^{2}$ of 0.181 indicates a weak relationship between prediction and grouping. The overall prediction success was $92 \%$. The Wald criterion demonstrates that enjoyment and the overall attitude made a significant contribution to the prediction $(p=0.003, p<0.01)$. Exp $(B)$ values indicate that when enjoyment is raised by one unit the odds ratio is 2 times as large, thus students are 2 times more 
likely to score a pass grade. When attitude is raised by one unit, students are likely to score a pass grade by the same amount. Tables 10 (a) and (b) summarize the findings.

Table 10 (a). Binary Logistic regression analysis between attitude aspects and performance

\begin{tabular}{lccccc}
\hline & B & S.E & Wald & Sig. & Exp (B) \\
\hline Constant & -3.66 & 0.835 & 19.25 & 0.000 & 0.026 \\
\hline Confidence & 0.259 & 0.248 & 1.092 & 0.296 & 1.295 \\
\hline Enjoyment & 0.698 & 0.235 & 8.85 & 0.003 & 2.009 \\
\hline Usefulness & 0.145 & 0.253 & 0.328 & 0.567 & 1.156 \\
\hline Anxiety & 0.203 & 0.155 & 1.717 & 0.190 & 1.225 \\
\hline Motivation & 0.299 & 0.172 & 3.026 & 0.082 & 1.348 \\
\hline \multicolumn{1}{c}{382.175, Negelkerke } & \\
\hline
\end{tabular}

$-2 \mathrm{LL} \quad 382.175$, NegelkerkeR ${ }^{2}=0.18$, Hosmer and Lemeshow $\mathrm{p}=0.259$

Table 10 (b). Binary Logistic regression analysis between Attitude and performance

\begin{tabular}{lccccc}
\hline Constant & -3.637 & 0.791 & 21.127 & 0.000 & 0.026 \\
\hline Attitude & 1.589 & 0.220 & 52.281 & 0.000 & 4.897 \\
\hline $2 \mathrm{LL}$ & &
\end{tabular}

-2LL 385.885 , NegelkerkeR2 $=0.18$, Hosmer and Lemeshow $\mathrm{p}=0.046$

\section{DISCUSSION}

The paper sought to investigate students' attitudes towards learning mathematics among a sample of 869 students in Tanzania. The paper specifically sought to establish the reasons behind students like or dislike of mathematics and the relationship between attitude, attitude aspects and performance. The results show that a large proportion of students exhibited a positive attitude towards mathematics.

\section{Students' Attitude towards Learning Mathematics}

The results show that students had a positive attitude towards mathematics, but the attitude became less positive in secondary schools through college. This result corroborates earlier findings (Mata et al., 2012). Their study reveals that 2 nd cycle students had positive attitudes while the mean scores of secondary students dropped below the midpoint of the scale. They explain that the decrease in attitude could be related to curriculum organisation as students' advanced in school education, the curriculum became more demanding, requiring a more abstract level of understanding. However, the results of this study contradict earlier findings conducted in Tanzania by Joseph (2013) who found that $55 \%$ of secondary students showed an overall negative attitudes towards mathematics. The reasons could be that their study was conducted in community secondary schools characterised by shortage of teachers and challenged with scarcity of teaching-learning resources. We observed also that students disliked mathematics when teaching-learning materials and resources are scarce.

\section{Relationship among Attitude Aspects, Attitude, and Student Performance}

The results indicate a significant positive, but weak correlation among attitude aspects, attitudes, and mathematics grade (see Table 9), which is consistent with Mata, et al. (2012). The results also show that all attitude aspects were highly positively correlated with attitude, but the highest correlation occurred between usefulness $(r=0.811)$, confidence $(r=0.784)$, enjoyment $(r=0.773)$, motivation $(r=0.701)$ and attitude. This indicates that these factors contributed significantly to the formed attitudes, and that as these variables increased students' attitudes became more positive. Qualitative results indicate also that mathematics usefulness, enjoyment, confidence, and motivation were key to students' engagement in mathematics. The responses showed that students liked mathematics because they enjoyed, had self-confidence and were motivated to do so.

This is in line with OECD (2013); Van der Bergh (2013); Zakaria and Nordin (2008) who posit that these factors are crucial in shaping students' attitudes and consequently their achievement in mathematics. However, the regression analysis of our data shows that in Tanzania, only the enjoyment of mathematics significantly predicted the students' performance. This means that students learn better, when they enjoyed the lessons. Therefore, it is up to teachers to employ strategies that will make mathematics lessons more enjoyable. The study by Ngussa and Mbuti (2017) shows that using humour as a teaching strategy makes a lesson interesting and enjoyable as a result students' perform better. 


\section{Reasons for a Like or Dislike of Mathematics}

The results show that students liked mathematics because they saw its value in everyday life, and they found mathematics interesting and enjoyable. They possessed self-confidence to do well in mathematics which is in line with Van der Bergh (2013) who found a significant influence between self-confidence and students' ability to successfully learn and perform well in mathematics. The study of Syyeda (2016) also supports this finding as it was found that despite negative emotions, students' valued mathematics in future and their present lives.

It was revealed that having a good teacher and good result, career prospects and support of teachers, parents and peers were also important for students liking of mathematics. This result is similar to that of Simmers (2011) and Yllmazet et al. (2010). When it comes to teachers, students wanted teachers to deliver material clearly as they were the ones who would make lessons enjoyable. They were to be tolerant, and a kind. In Simmers (2011), it was established that when a student thought of a teacher as good or if they liked him or her this could affect their intrinsic and extrinsic motivation to learn the subject in a positive way.

With respect to career prospects, in our study it is related to both liking and disliking of mathematics while in Simmers', it is linked with a dislike of mathematics. In our study, it was found that students wanted to see a link between mathematics and various occupations once this link is not clear students dislike mathematics. On having good results, Ignacio et al. (2006) found that receiving a good grade motivated students and improved their self-concept as learners of mathematics as this made them feel more complete and capable.

With regard to students' need of teacher support, Blazar and Kraft (2017) found that emotional support was associated with an increase in students' self-efficacy in mathematics and their happiness in class. They discussed further that by providing emotional support and a predictable, consistent and safe environment it could help them become self-reliant, motivated to learn and ready to take risks. In our study, support encompassed academic and emotional support from teachers, parents, and peers.

Also, students' lack of confidence ("I'm not good at math"), seeing mathematics as difficult, the applicability of the subject matter and receiving a poor grade explain students' mathematics aversion. This is consistent with Simmers (2011) who found that students' aversion of mathematics is linked with the applicability of mathematics in real-life situations. Beliefs that mathematics is difficult and having a bad grade for the exam. When it comes to self-confidence, Van der Bergh (2013) argues that when a student possesses high confidence and he or she believes in their abilities of becoming successful in mathematics, they are likely to overcome the fear of failing. However, simmers (2011) is of the view that the issue here is persistence. He says that students should not allow one bad experience to ruin their future attainment in mathematics.

\section{I like mathematics, but....}

It was found that the various factors hindering students' learning of mathematics constituted student characteristics, teacher characteristics and class/school administration factors which is consistent with the results by Yang (2013).

Student characteristics involve the lack of seriousness, fear of mathematics, fear of the teacher being angry, and fear of failing. This result is in line with Yılmazet al. (2010) who found that students' disliked mathematics when they were punished, and when they did not understand the topic well.

Regarding perception about teacher characteristics, the respondents linked this with teachers' ineffectiveness in relation to inappropriate teaching methods. This in line with the findings by Tshabalala and Ncube (2016) who found that mathematics teachers used methods that learners did not follow easily. The other factor related to teacher ineffectiveness is to do with pace of instructions, teachers' failure to support students with problems, and their perceptions about students' ability. These findings are in line with Simmers (2011) who reveals that pace of instruction, teachers' perception towards students' ability, and failure to provide support to students with problems greatly affected students' learning in a negative way. One reason for the high pace of instruction could be the content breadth that needed to be covered within a specified time. As a result, teachers failed to take care of diverse learning needs, hence affecting students' learning. Simmers (2011) discusses further as he says that research in the structuring and delivery of mathematics instruction suggests that at each grade level students cover relatively few topics, but in great depth. In this way, teachers would not have to rush to cover many things, leaving students with difficulties unattended. However, this may not be within the capacity of individual teachers. It should also be the concern and the actions of education 
administrators and policy makers in effecting the necessary changes regarding the amount of content to be covered that have a direct effect to the pace of instruction.

With regard to the teacher's perception of their students, Simmers (ibid) discusses that processes that create insecurities in mathematics ability, making students feel stupid and lower self-esteem affect them in a negative way. On the provision of support to students, Sakiz, et al. (2012) show that teachers' affective support may be critical for the students' cognitive, emotional, and motivational well-being as it promotes enjoyment, self-efficacy, and academic effort in mathematics.

With respect to educational administration factors, it was revealed that the shortage of teachers, scarcity of teaching, and learning resources, and English language problems among secondary school students hindered their learning. This finding is consistent with Joseph (2013) who found that the shortage of teachers and learning resources was consistent among secondary schools investigated in Kagera region. It was found that in all schools, there were few mathematics teachers, books, and other teaching and learning instruments such as black boards, rulers, set square, geometric models, and mathematics laboratory just to mention a few. Enu et al. (2015) suggest that teaching resources such as geometry sets, mathematical models, and others are crucial in enhancing students' understanding of mathematical concepts. On the other hand, English is a language of instruction in secondary schools, but students struggle to understand instructions given in English which affects the learning process of the subject content. This is because in Tanzania, English is introduced at secondary school while in primary schools, students learn by using Kiswahili. So, they fail to cope with the language. As a result, they fail to understand instructions leading to failures in mathematics.

The results of the present study show also that discouragement from peers affected students' learning and their attitude towards mathematics. According to He (2007) peer influence is a very important factor that can significantly affect students' perception towards mathematics. In this study, it was found that adolescents' perceptions of their own mathematics attitude were positively correlated with perception of peer attitudes. Further explanations could be that students spent much time with peers in schools or colleges. While in school, students met and interacted with different individuals in a variety of ways. In doing so, they communicated and learned from peers who at times could be a bad or good influence on them. This would affect their perception about mathematics. Also, friends talking while studying or in the classroom was reported to affect students' understanding of mathematics. Yılmaz, et al., (2010) found similar results where students reported to develop a dislike of mathematics when a friend was talking during classes.

Our study also reveals that respondents felt that teachers' failure to complete the syllabus affected them greatly. This is similar to the finding by Tshabalala and Ncube (2016). In addition, our study reveals that students' failure to finish examination due to poor learning and examination strategies were among the factors influencing students' performance of mathematics in examinations.

\section{Students Like or Dislike of Mathematics vs. Walberg's Theory of Productivity}

Walberg's Theory of Productivity specifies nine factors that should be considered so as to enhance students' affective, behavioural and cognitive learning (Walberg, et al., 1986; Waldrip \& Giddings, 1994; Bruinsma \& Jansen, 2007). The first group of factors includes aptitude variables that contain students' motivation and ability (prior achievement). Students' motivation is indicated by the belief that they can learn mathematics, feeling of responsibility to undertake the mathematical tasks, finding mathematics interesting, perseverance, and a positive feeling that when they do mathematics tasks they are likely to apply the appropriate cognitive strategies. Prior achievement is related to the students' belief that positive results in previous examinations will support their learning of mathematics.

The second group of factors includes those instructional practices that affect students' learning of mathematics, notably quantity and quality of instructions. The quantity of instructions is defined by the amount of time students spend on learning mathematics either in the classroom or outside school hours, i.e. students find time to learn mathematics or the feeling that they have little time to actually work on mathematical tasks. The quality of instruction is indicated by the extent to which the topic is clear to students, the presentation aspects that include organisation of information, use of clear and understandable language. Other indicators are, for example "teaching is good", "pace of instruction (high/low)" as well as "quality of content" (Bruinsma \& Jansen, 2007). Waldrip and Giddings (1994) state that despite the fact that no one factor can be sufficient in itself, the factors discussed in the first and the second group are seen as crucial for students' learning. 
The last group involves the psychological-environmental factors that include peer group, home environment, class/school environment and students' exposure to mass media (Bruinsma \& Jansen, 2007).

The Walberg's Theory is relevant to guide our discussions regarding factors influencing students' attitude (a like or dislike) towards mathematics and those affecting their learning and performance. Factors that guide our discussion include: Students motivation, and prior achievement; quality and quantity of instruction; home, school and peer environment; and mass media specifically availability of computers. These factors are relevant to our study because they are considered to be the main determinants of the learning process (Bruinsma \& Jansen, 2007).

The results presented in Table 11 are consistent with the conceptualization of the Walberg's productivity theory with the exception of developmental age. This means that for the students sample surveyed in Tanzania student aptitude variable constitute prior achievement and motivation.

Table 11. Discussion of our findings based on Walberg's Theory of Productivity

\begin{tabular}{|c|c|c|}
\hline $\begin{array}{l}\text { Walberg's } \\
\text { variables }\end{array}$ & $\begin{array}{l}\text { Description of factors affecting } \\
\text { affective, behavioural and cognitive } \\
\text { learning }\end{array}$ & Our findings \\
\hline \multirow[t]{2}{*}{$\begin{array}{l}\text { Student } \\
\text { Aptitude } \\
\text { attributes }\end{array}$} & $\begin{array}{l}\text { Prior achievement: achievement in math } \\
\text { tests and examinations. It also } \\
\text { encompasses background in mathematics }\end{array}$ & $\begin{array}{l}\text { - Background knowledge in mathematics } \\
\text { - Poor background knowledge } \\
\text { - Previous results in tests or exams } \\
\text { - Good results result in a like } \\
\text { - Bad grade result in a dislike }\end{array}$ \\
\hline & $\begin{array}{l}\text { Motivation: stands for academic } \\
\text { motivation which can be positive, i.e. } \\
\text { perseverance and students' belief they } \\
\text { can learn or negative }\end{array}$ & $\begin{array}{l}\text { - Use of appropriate cognitive strategies: - reported poor learning and } \\
\text { examination strategies (do not use appropriate cognitive strategies) } \\
\text { - Perseverance: } \\
\text { - Lack of seriousness (failing to allocate time for private studies) } \\
\text { - Feeling math is difficult } \\
\text { - Self-concept; belief that they are not good (students do not want to try } \\
\text { hard) } \\
\text { - Feeling that mathematics is easy }\end{array}$ \\
\hline \multirow[t]{2}{*}{ Instruction } & Quantity - time of instructions & $\begin{array}{l}\text { - Content coverage: failure to cover syllabus- teachers rush to cover the } \\
\text { syllabus (inadequate time spent on teaching) }\end{array}$ \\
\hline & $\begin{array}{l}\text { Quality- mathematics teacher instruction } \\
\text { delivery and the quality of examinations }\end{array}$ & $\begin{array}{l}\text { - Pace of instruction- teachers move faster } \\
\text { - Content clarity: } \\
\text { - Instructional strategies (ineffective), teachers use of punishment causes } \\
\text { fear of the subject and the teachers } \\
\text { - Teachers content area knowledge (reported poor) } \\
\text { - Linkage to real-life applications (Irrelevance of some topics to daily } \\
\text { life), a teacher's failure to provide examples linking mathematics to } \\
\text { real-life applications } \\
\text { - Language clarity: Use of English is a problem for secondary school } \\
\text { students. Students fail to understand instructions } \\
\text { - The Quality of assessment: Failing to complete examinations due to long } \\
\text { examinations in relation to time allocated (reported by primary and } \\
\text { secondary school students) } \\
\text { - Teacher support } \\
\text { - The lack of support from teachers (few teachers are unable to provide } \\
\text { the needed support to students) } \\
\text { - Teachers' perception about students' ability is not supportive }\end{array}$ \\
\hline \multirow[t]{5}{*}{$\begin{array}{l}\text { Social } \\
\text { psychological } \\
\text { environment }\end{array}$} & $\begin{array}{l}\text { Home environment: This may include } \\
\text { parent's supporting and encouraging } \\
\text { their students to study mathematics }\end{array}$ & - Parents are supportive and encouraging \\
\hline & $\begin{array}{l}\text { Class environment: conducive for } \\
\text { learning, i.e. noisy-free, tension-free }\end{array}$ & $\begin{array}{l}\text { - Friends talking in the classroom -(noises were reported by secondary } \\
\text { school students as a problem) } \\
\text { - Uneasy/fearful (make math less enjoyable) } \\
\text { - Teachers are angry } \\
\text { - The use of punishment }\end{array}$ \\
\hline & School environment & $\begin{array}{l}\text { - Inadequate number of teachers and teaching-learning resources such as } \\
\text { - Books, geometrical sets, math laboratories, blackboards... }\end{array}$ \\
\hline & Peer environment & $\begin{array}{l}\text { - Peer support } \\
\text { - Supportive (like math) } \\
\text { - Discouraging (dislike mathematics) }\end{array}$ \\
\hline & $\begin{array}{l}\text { Mass media: use of computers to } \\
\text { mathematics }\end{array}$ & $\begin{array}{l}\text { - The lack of computers is a problem for students (secondary school } \\
\text { students reported) }\end{array}$ \\
\hline
\end{tabular}




\section{LIMITATIONS}

The study has involved public schools and colleges from only one district in each of five regions visited out of over 30 regions. The schools were sampled from urban and suburban areas. Hence, the sample may not represent students from private schools and rural areas. Future studies should consider also private and rural schools. The study is also limited to only students' individual factors associated with attitudes towards mathematics. Nevertheless, there are other factors such as teachers' attitude towards students and students' attitude towards school, which should be the focus of future studies in Tanzania. The study used self-reported mathematics grade that might have caused some bias. Future studies should consider students' scores from school records.

Despite the limitations, the study findings expand the pool of research by adding empirical evidences in support of the recent trends that students' attitudes are positive, but become less positive as they advance in school education. It was also found that among the attitude components only mathematics enjoyment affected students' performance. This is significant given claims that attitudes influence students' learning and performance. The results of this study provide insights for future research and inciting changes in teaching practices that would promote enjoyment and positive attitudes towards mathematics and consequently students' performance.

\section{CONCLUSIONS AND RECOMMENDATIONS}

The study found that students exhibited a positive attitude towards mathematics. However, this starts changing when students enter secondary schools. Despite the number being small, negative attitudes may have a greater effect on students' learning, thus it should not be ignored.

Despite the fact that more than $80 \%$ of students exhibit positive attitude towards mathematics, the majority are failing their mathematics examinations. From our work, we understood that the problem is not only on the students' attitude toward the subject but there are other factors affecting their grades. In regards to our findings these factors include didactic strategies used by mathematics teachers to deliver instructions and institutional resources. Moreover, it was found that students do enjoy mathematics, but they have failed their examinations likely due to poor learning and examination strategies and the lack of understanding the language of instruction due to English language deficiencies.

Based on the findings, the study recommends that, teachers should appropriately adopt instructional techniques that include learners' diversities or barriers to learning, minimise fear, enhance active interest, and enjoyment in what is being taught and learnt. They should apply corrective measures that will reduce tension and provide support to their students whenever they may require. This will foster mutual understanding in a non-threatening teaching and learning environment. Furthermore, students should use their time wisely so that they can have enough time to practice and internalise mathematical concepts learned in classrooms. They should be taught to apply the appropriate strategies for learning and taking mathematics examinations. Students should be assisted to enhance their English language skills from primary schools. This may help them acquire competencies, and thus improve their mathematics performance. The government should provide teaching and learning resources. These should include enough qualified teachers, books, computers, and other instructional materials for effective learning of mathematics.

\section{Disclosure statement}

No potential conflict of interest was reported by the authors.

\section{Notes on contributors}

Mzomwe Yahya Mazana - College of Business Education, Dar es Salaam, Tanzania, and University of Eastern Finland, School of Computing, Joensuu, Finland.

Calkin Suero Montero - University of Eastern Finland, School of Computing, Joensuu, Finland.

Respickius Olifage Casmir - College of Business Education, Dar es Salaam, Tanzania. 


\section{REFERENCES}

Abe, T. O., \& Gbenro, O. S. (2014). A Comparison of Students' Attitudinal Variables towards Mathematics between Private and Public Senior Secondary Schools. Journal of Educational Policy And Entrepreneurial Research, 1(1), 32-39. Retrieved from http://jeper.org/index.php/JEPER/article/ viewFile/4/4

Adelson, J. L., \& McCoach, D. B. (2011). Development and psychometric properties of the math and me survey: Measuring third through sixth graders' attitudes toward mathematics. Measurement and Evaluation in Counselling and Development, 44(4), 225-247. Retrieved from https://journals.sagepub.com/doi/pdf/ 10.1177/0748175611418522?casa_token

Ajzen, I. (1993). Attitude theory and the attitude-behavior relation. New directions in attitude measurement, 41-57.

Ajzen, I., \& Fishbein, M. (1977). Attitude-behavior relations: A theoretical analysis and review of empirical research. Psychological bulletin, 84(5), 888. http://www.thecre.com/tpsac/wp-content/uploads/2011/02/ Appendix2_AttitudevsAction_ByAjzenFishbein1977.pdf

Akinsola, M. K., \& Olowojaiye, F. B. (2008). Teacher Instructional Methods and Student Attitudes towards Mathematics. International Electronic Journal of Mathematics Education, 3(1), 60-73. http://www. iejme.com/download/teacher-instructional-methods-and-student-attitudes-towards-mathematics.pdf

Bethell, G. (2016). Mathematics Education in Sub-Saharan Africa: Status, Challenges, and Opportunities. World Bank. Retrieved from https://openknowledge.worldbank.org/handle/10986/25289

Blazar, D., \& Kraft, M. A. (2017). Teacher and teaching effects on students' attitudes and behaviors. Educational evaluation and policy analysis, 39(1), 146-170. https://journals.sagepub.com/doi/pdf/10. 3102/0162373716670260

Bruinsma, M., \& Jansen, E. P. (2007). Educational productivity in higher education: An examination of part of the Walberg educational productivity model. School Effectiveness and School Improvement, 1, 45-65. Retrieved from https://www.tandfonline.com/doi/abs/10.1080/09243450600797711

Chaman, M., \& Callingham, R. (2013). Relationship between Mathematics Anxiety and Attitude towards Mathematics among Indian Students. Mathematics Education Research Group of Australasia, (pp. 138145). Melbourne. Retrieved from https://files.eric.ed.gov/fulltext/ED572799.pdf

Denscombe, M. (2010). The Good Research Guide: for small-scale social research. (4th ed.). McGraw Hill.

Einarsdóttir, J. (2007). Research with children: Methodological and ethical challenges. European early childhood education research journal, 15(2), 197-211. Retrieved from https://pages.shanti.virginia.edu/13sp_psyc_4559-003_cgas/files/2012/06/einarsdottir-2007.pdf

Enu, J., Agyman, O. K., \& Nkum, D. (2015). Factors influencing students' mathematics performance in some selected colleges of education in Ghana. International Journal of Education Learning and Development, 3(3), 68-74.

Fennema, E., \& Sherman, J. A. (1976). Fennema-Sherman mathematics attitudes scales: Instruments designed to measure attitudes toward the learning of mathematics by females and males. Journal for research in Mathematics Education, 7 (5), 324-32. Retrieved from https://www.jstor.org/stable/pdf/ 748467.pdf

Getahun, D. A., Adamu, G., Andargie, A., \& Mebrat, J. D. (2016). Predicting mathematics performance from anxiety, enjoyment, value, and self-efficacy beliefs towards mathematics among engineering majors. Bahir Dar j educ, 16(1). Retrieved from https://www.researchgate.net/publication/309703947

Guy, G. M., Cornick, J., \& Beckford, I. (2015). More than Math: On the Affective Domain in Developmental Mathematics. International Journal for the Scholarship of Teaching and Learning, 9 (2). Retrieved from https://files.eric.ed.gov/fulltext/EJ1134636.pdf

Hamilton, M., Mahera, W. C., Mateng'e, F. J., \& Machumu, M. M. (2010). A needs assessment study of Tanzania science education. The economic and social research foundation (ESRF), Dar es Salaam. Retrieved from http://www.unesco.org/new/fileadmin/MULTIMEDIA/HQ/SC/pdf/sc_A_Needs_ Assessment_Study_of_Tanzania_Science_Education.pdf

Hannula, M. S., Maijala, H., \& Pehkonen, E. (2004). Development of Understanding and Self-Confidence in Mathematics; 5-8., Grades. International Group for the Psychology of Mathematics Education. Retrieved from http://emis.ams.org/proceedings/PME28/RR/RR162_Hannula.pdf 
He, H. (2007). Adolescents' Perception of Parental and Peer Mathematics Anxiety and Attitude Toward Mathematics: A Comparative Study of European-American and Mainland-Chinese Students (Doctoral dissertation, Washington State University). Retrieved from http://citeseerx.ist.psu.edu/viewdoc/download?doi=10.1.1.632.1280\&rep=rep1\&type=pdf

Hoorfar, H., \& Taleb, Z. (2015). Correlation between mathematics anxiety with metacognitive knowledge. Procedia-Social and Behavioral Sciences, 182, 737-741. Retrieved from https://core.ac.uk/download/pdf/82718780.pdf

Hourigan, M., Leavy, A. M., \& Carroll, C. (2016). Come in with an open mind': changing attitudes towards mathematics in primary teacher education. Educational Research, 58(3), 319-346. Retrieved from https://www.tandfonline.com/doi/abs/10.1080/00131881.2016.1200340

Ignacio, N. G., Nieto, L. J., \& Barona, E. G. (2006). The affective domain in mathematics learning. International Electronic Journal of Mathematics Education, 1(1), 16-31. Retrieved from http://www.iejme.com/download/the-affective-domain-in-mathematics-learning.pdf

Joseph, G. (2013). A Study on School Factors Influencing Students'Attitude Towards Learning Mathematics in the Community Secondary Schools in Tanzania: The case of Bukoba Municipal Council in Kagera Region. (Masters dissertation). Retrieved from http://repository.out.ac.tz/919/

Kibrislioglu, N. (2015). An Investigation About 6th Grade Students' Attitudes Towards Mathematics. Procedia-Social and Behavioral Sciences, 186, 64-69. https://doi.org/10.1016/j.sbspro.2015.04.024

Kothari, C. (2004). Research Methodology Methods \& Techniques. New Delhi: New Age International (P) Ltd.

Kupari, P., \& Nissinen, K. (2013). Background factors behind mathematics achievement in Finnish education context: Explanatory models based on TIMSS 1999 and TIMSS 2011 data. IEA CONFERENCE 2013, Proceedings. Retrieved from https://www.iea.nl/fileadmin/user_upload/IRC/IRC_2013/Papers/IRC2013_Kupari_Nissinen.pdf

Lipnevich, A. A., MacCann, C., Krumm, S., Burrus, J., \& Roberts, R. D. (2011). Mathematics attitudes and mathematics outcomes of US and Belarusian middle school students. Journal of Educational Psychology, 103 (1), 105. Retrieved from https://www.researchgate.net/profile/Jeremy_Burrus/ publication/232478953

Mabula, S. (2015). Modelling Student Performance in Mathematics Using Binary Logistic Regression at Selected Secondary Schools a Case Study of Mtwara Municipality and Ilemela District. Journal of Education and Practice, 6(36), 96-103. Retrieved from https://files.eric.ed.gov/fulltext/EJ1086512.pdf

Mata, M. D., Monteiro, V., \& Peixoto, F. (2012). Attitudes towards mathematics: Effects of individual, motivational, and social support factors. Child development research, 2012. https://doi.org/10.1155/2012/876028

Mensah, J. K., Okyere, M., \& Kuranchie, A. (2013). Student attitude towards Mathematics and performance: Does the teacher attitude matter? Journal of Education and Practice, 4(3), 132-139.

Ministry of Education and Vocational Training. (2007). Curriculum for ordinary level secondary education in Tanzania (2013 ed,). Dar es Salaam: Tanzania Institute of Education.

Mohamed, L., \& Waheed, H. (2011). Secondary students' attitude towards mathematics in a selected school of Maldives. International Journal of humanities and social science, 1(15), 277-281. Retrieved from https://www.researchgate.net/profile/Hussain_Waheed/publication/266009828

Mohamed, S. H., \& Tarmizi, R. A. (2010). Anxiety in mathematics learning among secondary school learners: A comparative study between Tanzania and Malaysia. Procedia-Social and Behavioral Sciences, 8, 498504. https://doi.org/10.1016/j.sbspro.2010.12.068

Mutai, K. J. (2011). Attitudes towards learning and performance in mathematics among students in selected secondary schools in Bureti district, Kenya (Masters Dissertation). Retrieved from http://irlibrary.ku.ac.ke/bitstream/handle/123456789/609/JACKSON\%20KIPRONOH.pdf

National Examinations Council of Tanzania (NECTA) (2016). Examination statistics. Dar es Salaam: National Examination Council of Tanzania.

Ngussa, B. M., \& Mbuti, E. E. (2017). The Influence of Humour on Learners' Attitude and Mathematics Achievement: A Case of Secondary Schools in Arusha City, Tanzania. Journal of Educational Research, 2(3), 170 -181. Retrieved from https://www.researchgate.net/publication/315776039 
Nicolaidou, M., \& Philippou, G. (2003). Attitudes towards mathematics, self-efficacy and achievement in problem solving. European Research in Mathematics Education III. Pisa: University of Pisa, 1-11. Retrieved from http://www.dm.unipi.it/ didattica/CERME3/proceedings/Groups/TG2/TG2_nicolaidou_ cerme3.pdf

OECD. (2013). StudentS' drive and MotivatioN. Results: Ready to Learn-Students' Engagement, Drive and Self-Beliefs. Volume III. OECD. Retrieved from https:/www.oecd.org/pisa/keyfindings/pisa-2012results-volume-III.pdf

Patena, A. D., \& Dinglasan, B. L. (2013). Students' Performance on Mathematics Departmental Examination: Basis for Math Intervention Program. Asian Academic Research Journal of Social Science \& Humanities, 1(14), 255-268.

Phonapichat, P., Wongwanich, S., \& Sujiva, S. (2014). An analysis of elementary school students' difficulties in mathematical problem solving. Procedia-Social and Behavioral Sciences, 116, 3169-3174. Retrieved from https://www.researchgate.net/profile/Suwimon_Wongwanich/publication/270847106

Randolph, J. J. (2008). Multidisciplinary Methods in educational technology Research and Development. Finland: HAMK publishers.

Sakiz, G., Pape, S. J., \& Hoy, A. W. (2012). Does perceived teacher affective support matter for middle school students in mathematics classrooms? Journal of School Psychology, 50(2), 235-255. Retrieved from https://www.sciencedirect.com/science/article/pii/S0022440511000859

Sarmah, A., \& Puri, P. (2014). Attitude towards Mathematics of the Students Studying in Diploma Engineering Institute (Polytechnic) of Sikkim. Journal of Research \& Method in Education, 4(6). Retrieved from http://www.academia.edu/download/36434404/B04630610.pdf

Schofield, H. L. (1982). Sex, grade level, and the relationship between mathematics attitude and achievement in children. The Journal of Educational Research, 75(5), 280-284. Retrieved from https://www.tandfonline.com/doi/abs/10.1080/00220671.1982.10885395

Shaw, C., Brady, L.-M., \& Davey, C. (2011). Guidelines for Research with Children and Young People. London: NCB Research Centre. Retrieved from https://www.researchgate.net/profile/LoucaMai_Brady/publication/260060346

Simmers, M. J. (2011). It's Not the math They Hate. Hawaii University International Conference On Mathematics and Engineering, (pp. 1-48). Hawaii.

Sundre, D., Barry, C., Gynnild, V., \& Ostagard, E. T. (2012). Motivation for achievement and attitudes toward mathematics instruction in a required calculus course at the Norwegian University of Science and Technology. Numeracy, 5(1), 4. Retrieved from http://scholarcommons.usf.edu/numeracy/vol5/iss 1/art4/

Syyeda, F. (2016). Understanding Attitudes Towards Mathematics (ATM) using a Multimodal modal Model: An Exploratory Case Study with Secondary School Children in England. Cambridge Open-Review Educational Research e-Journal, 3, 32-62. Retrieved from http://corerj.soc.srcf.net/?page_id=224

Tahar, N. F., Ismail, Z., Zamani, N. D., \& Adnan, N. (2010). Students' Attitude Toward Mathematics: the use of Factor Analysis in Determining the Criteria. Procedia Social and Behavioral Research, 8, 476-481. Retrieved from https://www.sciencedirect.com/science/article/pii/S1877042810021701

Gonzales, P., Williams, T., Jocelyn, L., Roey, S., Kastberg, D., \& Brenwald, S. (2008). Highlights from TIMSS 2007: Mathematics and Science Achievement of US Fourth-and Eighth-Grade Students in an International Context. NCES 2009-001. National Center for Education Statistics. Retrieved from https://eric.ed.gov/?id=ED503625

Tshabalala, T., \& Ncube, A. C. (2016). Causes of poor performance of ordinary level pupils in mathematics in rural secondary schools in Nkayi district: Learner's attributions. Nova Journal of Medical and Biological Sciences, 1(1). Retrieved from http://nova-jmbs.com/index.php/jmbs/article/view/13

Van der Bergh, E. (2013). The influence of academic self-confidence on mathematics achievement. Doctoral dissertation, North-West University.

Walberg, H. J., Fraser, B. J., \& Welch, W. W. (1986). A test of a model of educational productivity among senior high school students. The Journal of Educational Research, 79(3), 133-139. Retrieved from https://www.tandfonline.com/doi/abs/10.1080/00220671.1986.10885664

Waldrip, B. G., \& Giddings, G. J. (1994). Educational Productivity, Pedagogy and Culture. The Annual Meeting of the American Educational Research Association April 4 - 8, New Orleans. Retrieved from https://eric.ed.gov/?id=ED372965 
Yang, X. (2013). Senior Secondary Students' Perceptions of Mathematics Classroom Learning Environments in China and Their Attitudes towards Mathematics. The Mathematics Educator, 15(1), 66-80. Retrieved from http://math.nie.edu.sg/ame/matheduc/tme/tmeV15_1/4.pdf

Yllmaz, C.., Altun, S. A., \& Olkun, S. (2010). Factors affecting students' attitude towards Math: ABC theory and its reflection on practice. Procedia-Social and Behavioral Sciences, 2(2), 4502-4506. Retrieved from https://www.sciencedirect.com/science/article/pii/S1877042810007603

Yunus, A. S., \& Ali, W. Z. (2009). Motivation in the Learning of Mathematics. European Journal of Social Sciences, 7(4), 93-101. Retrieved from https://core.ac.uk/download/pdf/42993965.pdf

Zakaria, E., \& Nordin, N. M. (2008). The Effects of Mathematics Anxiety on Matriculation Students as Related to Motivation and Achievement. Eurasia Journal of Mathematics, Science \& Technology Education, 4(1), 27-30. 